\title{
Procedure to evaluate and control efficiently the operations management of medical equipment in the maintenance unit of a health institution
}

\section{Procedimiento para evaluar y controlar de forma eficiente la gestión operativa de equipos médicos en la unidad de mantenimiento de una entidad de salud}

\author{
Herrera-Galán Michael \\ Departamento de Bioingeniería \\ CUJAE, Centro Universitario José A. Echeverría \\ E-mail:michael830905@gmail.com
}

\author{
Natasha-Walker Shanique \\ Departamento de Bioingeniería \\ CUJAE, Centro Universitario José A. Echeverría \\ E-mail:walk_shan@yahoo.com
}

\begin{abstract}
Maintenance management plays a very important role in the success of any company. As a consequence of this, in the year of 2013, a study was carried out in health facilities found in the South Eastern Region of Jamaica with the objective of evaluating the existing Maintenance Management Program for Medical Equipment. Among the results obtained, it showed that there is an inadequacy in the existing program whose principal deficiency is attributed to the operations management. As such, this work proposes a procedure for evaluating and controlling in an efficient manner the operations management within the Biomedical Department which forms part of the South East Regional Health Authority Maintenance Unit (SERHAMU), this latter is found on the premises of the Bustamante Hospital for Children (BHC), Jamaica. The method used to develop the procedure (GOMHO) is based fundamentally on the design of: a codification system to identify control registers and to record failures associated with each equipment, a system of placing equipment into categories and further differentiating them based on the potential hazard such pose on the human body in the event of an operational failure. In addition, this procedure gives the SERHAMU at the BHC the opportunity to calculate the amount of human resources needed to carry out efficiently the preventative and corrective maintenance work being demanded on the department. During the implementation phase, the results demonstrated that from the control procedure designed there was an improvement in the planning and carrying out of maintenance work and a better system of monitoring the activities that are executed. Also, it was evidenced that there is a $61.53 \%$ of the amount of human resources needed to carry out the maintenance actions.
\end{abstract}

Keywords: maintenance, operations management, procedure.

\section{Resumen}

La gestión de mantenimiento juega un papel importante en el éxito de cualquier empresa. Como consecuencia de esto, durante el año 2013, se realizó un estudio con el objetivo de evaluar el Programa de Gestión de Mantenimiento de los equipos médicos en la Región Sur-Este de Jamaica. Los resultados del estudio demostraron, entre otros, que existe una inadecuada gestión de mantenimiento, cuya deficiencia principal se atribuye a su gestión operativa. Por tanto, este trabajo propone un procedimiento para evaluar y controlar de forma eficiente la gestión operativa en la Unidad de Mantenimiento de la Autoridad de Salud para la Región Sur-Este (SERHAMU) del Hospital Pediátrico Bustamante (BHC) en Jamaica. El método utilizado para desarrollar el procedimiento $(\mathrm{GOMHO})$ se basó fundamentalmente en el diseño de un sistema de codificación para identificación de equipos y sus fallos y un sistema de clasificación y diferenciación basado en la vulnerabilidad del cuerpo humano ante un fallo potencial o mal funcionamiento del activo. Adicionalmente permite optimizar las funciones de un departamento de mantenimiento en una entidad hospitalaria bajo el criterio de determinar el personal necesario para ejecutar las acciones de mantenimiento proactivas y reactivas. Durante la fase de implementación, los resultados demostraron que con la aplicación del procedimiento se obtuvo una mejora en la planificación y ejecución de los trabajos de mantenimiento, así como un mejor control en el sistema de seguimiento de las actividades que se ejecutan. Asimismo, se evidenció que existe $61.53 \%$ de la cantidad necesaria de recursos humanos necesaria para ejecutar las acciones de mantenimiento.

Descriptores: mantenimiento, gestión operativa, procedimiento. 


\section{INTRODUCTION}

Whilst there is a rapid growth in technological tendencies, the focus on maintenance is evolving at a very slow pace. This is observed through the few results published from projects carried out over the years by wellknown and recognized international organizations (Zavarce et al., 2012). These organizations did not expect that the need for more focus on maintenance would be forthcoming neither that it would develop with new tendencies which would add new meanings to former concepts in the area of maintenance. Wherein, the objective of these new tendencies would be: obtaining an efficient and effective maintenance system and as such a reduction in the operations cost.

Even though production is a vital area to take into consideration when managing health institutions, this will not be discussed here as this work focuses only on the maintenance aspect of hospital and clinical management. Certainly, an institution that wants to provide quality health services at a low cost should convert itself to a model of superior excellence.

Presently, management is termed as those activities which can be rebounded on the growth of an organization. In maintenance management the primary objective is to increase the availability of installed assets at a low cost. Availability in the operations context is defined as assets functioning in an efficient and reliable manner. It is important to note that for any company to successfully compete with its counterparts it must possess some benefits that will allow it to make strides (CCEEM, 2008).

Therefore, the approach to optimize resources, costs and efforts will come from the common integration of all those concepts whose management has common aspects and requirements. That is; a model that guarantees a correct operations management (Viveros et al., 2013; Márquez et al., 2008; Puerta, 2011).

There are authors who state that operations management is a process which gives direction, prepares and uses resources and efforts in order to reach the objectives or goals of an organization. All of this is achieved through a sequence of more defined activities which are assigned specific time periods (Correa, 2012).

According to Caro (2012), operations management in the managerial ambit refers to actions that a company takes in order to make its day to day existence. Others define it as a process that directives carry out with the objective of fulfilling the organization's policies (Carrillo, 2011; Arnoletto et al., 2009).

Referring to the above definitions; operations management has the following aspects:
- Analysis of internal situations (weaknesses and strengths) and of external situations (threats and opportunities).

- Identifying and diagnosing key elements, explanatory of the situation.

- Making goals which are geared towards the fundamental objective of the organization.

- Developing strategies that lead to achieving the set goals.

- Developing a program or calendar of time period over which each strategy is to be completed.

- Developing a system of indicators to measure and to evaluate the results.

An important factor to take into consideration when aiming towards efficient maintenance is the incorporation of technical application training which must then be one of the objectives in the operations management program. By doing so, the proper control, conservation status, operation and service conditions of the facilities, equipment and other elements are achieved. Since the latter will be treated with the most adequate and appropriate knowledge. In addition, other commodities such as comfort, safety and an ease in financial constraints will be gained (INSALUD, 1990).

It is well known that developing a maintenance plan and managing it brings great benefits for a company. These benefits can be summarized as (Zavarce et al., 2012; SIC, 2008; Brousse, 2011):

- An increase in quantity or quality of the activities by resource utilized.

- Reduction of the costs of the current production levels.

- A better identification of the requirements and a better response to the aspirations of citizens.

- Performing the obligations of the organization with greater impartiality.

- Availability of response and innovation.

A study done by Acosta and Troncoso (2011) in four healthcare institutions reflects weaknesses in their operations management, essentially caused by shortage of high-level specialists. The results indicate that tasks were done correctly at a very low average level of $26.57 \%$ in the four facilities studied. The main weaknesses identified were:

- Occupational competencies of the staff have not been established.

- There is not a computerized maintenance management system. 
- The staff is incomplete.

- Lack of technical training.

- Lack of control mechanisms.

- Non-existence of reports and information from the day to day activities.

- The design of maintenance work order with inadequate fields.

Moreover a study done by Calzadilla (2011) and entitled "Diagnosis of the maintenance management of hospital network of the Anzoátegui state, case: University Hospital of Dr. Luis Razetti", concludes that the hospital network is found in a critical condition with regards to its maintenance management as there is a lack in vision of its clinical engineering works. Similarly, a study done in Medellín, whose purpose was to characterize the maintenance management in emergency clinics and hospitals in the metropolitan area of Medellin in the period 2008-2009, concludes the existence of weaknesses in certain aspects of its management. These weak areas include: poor organization, low availability of spare parts and lack of technical training of service technicians (Murillo et al., 2013).

The benefits of an operations management program within a maintenance department can then be summarized as: the equipment are maintained and serviced at an acceptable standard, the facility improved and the overall efficiency of the department impacted positively thereof. It can also be stated that this operations management program is similar to any other program which needs continuous improvement to become more and more effective and become fine tuned to the needs of the department. Therefore an established methodology to evaluate and control the said is of paramount importance. This methodology should be flexible in the acceptance of new or modification of old: criteria, control tabs and methods whenever the need for change arises.

From the observations above it is proposed as fundamental objective to provide a procedure to evaluate and control in an efficient manner the operations management within the Biomedical Department which forms part of the South East Regional Health Authority Maintenance Unit (SERHAMU). The SERHAMU is found on the premises of the Bustamante Hospital for Children (BHC), Jamaica. This work is a solution to one of the recommendations in a previous study that was done at the said SERHAMU in the year 2013.

The objective of the previous work was to evaluate the existing Maintenance Management Program for medical equipment and seek solutions where possible. Among the results obtained, it showed that there is an inadequacy in the existing program whose principal deficiency is attributed to the operations management. This is evident from the poor culture of planning and executing maintenance work and a weak system of monitoring the activities that are executed in the department. Solutions to these weak aspects are addressed in this work.

The BHC was chosen as this was the closest to the SERHAMU but the results hold true for other hospitals in the region as they are all maintained by the same SERHAMU.

The south east region was selected as here is where most of the country's major hospitals are and as such this is where the highest quantity of class II and III equipment are found. The results obtained in this region can be extended to the rest of the country since the regions operate in a similar manner.

This work is different from others that have been published. The differences are in the fact that this work gives: a method on how to establish an inventory number for control registers and types of equipment failure; provides categories used for assigning risk levels to medical equipment and make mention of documentation containing the rules to be used when assigning risk level; presents a method by which equipment belonging to the same risk category can be further differentiated by assigning them a priority index. In addition it permits the controlling and optimization of the operations within a biomedical maintenance department as it presents procedures on how to determine and schedule maintenance frequency and how to calculate the amount of persons required in a department for both corrective and preventative maintenance.

\section{Methodology}

The method used is based on the design of a procedure GOMHO (Gestión Operativa del Matenimiento Hospitalaria) from its acronym in Spanish, which is orientated towards evaluating the operations management in a hospital maintenance program. The time span of implementing this procedure depends directly on the complexity of the hospital and the qualification level of the workers within the maintenance department. The results obtained here could be of interest to those who interact directly or indirectly with maintenance departments in hospitals.

In the following lines, the aspects to be analyzed in each phase of the procedure are summarized. These aspects are also used to define each phase of the procedure and are described as such: 


\section{CODIFICATION SYSTEM}

The objective here is to provide formats by which inventory numbers for control registers and codes for types of equipment failure can be assigned. The utilization of these is important as they reflect important data, provide easy referencing in future analysis and help in the good organization of the maintenance department.

As for the control registers, this code system allows them to be easily located in and retrieved from storage system and referred to during future analysis or reports. By making reference to the following format from Figure 1 inventory numbers for control registers can be established.

Where the letters represent the letter code assigned to each type of registers: for example the letter code that could be assigned to registers of the type "Work Request" is "wrqst"; the digits represent the last two digits of the year at the time of codification and the number represents the accumulative figure of same registers coded within a particular year.

Also for types of equipment failure, this code system allows them to be easily grouped which helps in making quick references to them in future analysis or reports. Types of failure can be coded according to the following format from Figure 2.

Where the letters represent the letter code assigned to each specialty within the department and the digits represent numbers assigned to a particular type of failure within the said specialty.

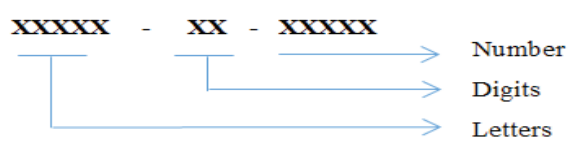

Figure 1. Format used to assign inventory numbers to control registers

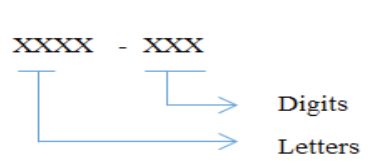

Figure 2. Format used to assign codes to types of equipment failure

\section{CLASSIFICATION OF EQUIPMENT INTO DIFFERENT RISK LEVELS}

The need to comply with regulatory requisites established in each country depends greatly on the risk level associated with the use of equipment. As such, the department needs to be aware of the fact that equipment can be classified into different risk levels, see Table 1. In the same manner, it should be stipulated within the department that equipment classified as high risk should be the first in receiving maintenance services and these services should be carried out by following procedures which are oriented towards guaranteeing the fulfillment of the regulatory requisites within that country. Taking this into consideration and the fact that up to the year of 2014, there has not been a risk classification system established for medical equipment in the country Jamaica, so for the fulfillment of this work the following classification rules will be adopted (CCEEM, 2008).

\section{CALCULATION OF PRIORITY INDEX}

The objective here is to provide a method by which equipment belonging to the same risk category can be further differentiated by assigning them a priority index. In this method, seven types of indices are provided and under each index there is a set of criteria. Table 2 mentions and describes the indices that will be used (David et al., 2004; Jardine et al., 2003).

To assign a priority index to equipment, the method consists in selecting a criterion under each of the seven indices and to sum the corresponding points which are associated with each criterion selected. Thus the priority index can be defined by the following equation (Dückers et al., 2009; David et al., 1996):

$P I=L+A+F+R+H+I U+D$

where

PI: Priority index

Table 1. Categories used for assigning risk levels to medical equipment

\begin{tabular}{ccc}
\hline Category & Risk level & Example of medical equipment \\
\hline I & Low risk & Surgical Retractor, tongue depressor \\
IIa & Moderate - low risk & Hypodermic needle, aspirator \\
IIb & Moderate - high-risk & Pulmonary ventilator, orthopedic implants \\
III & High risk & Cardiac valves, implantable defibrillator \\
\hline
\end{tabular}


DeteRMINATION OF INSPECTION AND PREVENTATIVE MAINTENANCE FREQUENCY

In a maintenance department it is advisable to group equipment into families and an inspection and preventative maintenance (IPM) frequency be obtained by averaging the IPM frequencies; these are specified by the manufacturers in the maintenance manuals. In the event that there are no maintenance manuals, the IPM frequency can be obtained by the following procedure:

- Group equipment into families and then into specialties.

- Assign a priority index to each family, this done by averaging the priority index assigned to each type of equipment within the family.

- Construct a histogram where the $\mathrm{x}$ axis values correspond to the range of priority index (in this case values range from 0 to 70 ) and the vertical rectangular heights correspond to the frequency with which families have the corresponding priority index.

- Once the histogram is obtained, a moving average trend line should be constructed on top of histogram so as to highlight the points where there are sharp changes in the height of the vertical rectangles.

- Regions can then be constructed by joining one changing point to a subsequent one or to further subsequent ones, no two regions should overlap and the amount of regions constructed should be equivalent to the highest IMP frequency that the department desires.

- The region that encloses the highest IP value should be interpreted as equipment families in that region be given the highest IPM frequency and equipment families in regions which are further away from the highest IP value be given lower and lower IPM frequency. See Figure 3.

\section{Calculation of the load of the annual maintenance PLAN}

The load of the annual maintenance plan depends on the following:

- Maintenance frequency

- Average hours to be dedicated to the maintenance of particular equipment family and

- Amount of equipment to be maintained

Following this, the load of the annual maintenance plan can be calculated according to the following formula:
$C P A=\sum_{i=0}^{n}\left(C E_{i} \times F M_{i} \times H P E_{i}\right)$

where

$\mathrm{n} \quad=$ Total families of equipment listed for maintenance

$\mathrm{CPA}=$ Load of the annual maintenance plan

$\mathrm{FM}=$ Maintenance frequency

$\mathrm{CE}=$ Amount of equipment in each family

$\mathrm{HPE}=$ Average hours to be dedicated to the maintenance of particular equipment family

The amount of time available per year to technicians for carrying out maintenance can be calculated according to the following formula

$F T=n \times\left[\left(J L-\sum H N D\right) \times\left(D M-\sum D N L\right)\right]$

where

$\mathrm{n}=$ Constant equivalent to the number of months

FT = Time available

$\mathrm{JL}=$ Duration of working shift

$\mathrm{DM} \quad=$ Amount of working days in each months

$\sum H N D=$ Sum of hours dedicated to breakfast, lunch, breaks etc.

$\sum D N L=$ Sum of non-working days in each month

Calculation of the minimal amount of Persons ReQuiRED IN THE DEPARTMENT

With the above results of the CPA and FT, a new factor can be calculated which is the minimal amount of persons required in the department $(\mathrm{PO})$; which is expressed by the following

$P O=\frac{C P A}{F T}$

\section{SCHEDULING MAINTENANCE}

Scheduling maintenance in a department is a continuous process as it entails the planning of events which are stable with time and others which are unstable (work request, follow-up etc.)

Even so, there should be a base upon which the maintenance is scheduled and a base which is characterized for its flexibility to incorporate the planning of those events which cannot be planned for (Brousse, 2011; Otero et al., 2010). Taking this into consideration, an effective manner of scheduling maintenance is proposed: 
DOI: http://dx.doi.org/10.22201/fi.25940732e.2018.19n1.001

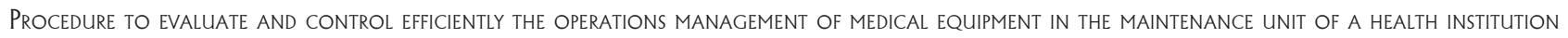

Table 2. Criteria used to calculate medical equipment priority index

\begin{tabular}{|c|c|c|}
\hline \multicolumn{2}{|c|}{ Determination of priority index based on risk } & \\
\hline \multicolumn{2}{|c|}{ Equipment location $(L)$} & \\
\hline \multicolumn{2}{|c|}{ Criterion } & Breakdown \\
\hline \multicolumn{2}{|c|}{ ICU, OT, accidents and emergency, labor and delivery room, anesthetics department } & 10 \\
\hline \multicolumn{2}{|c|}{ Blood bank, renal unit, sterilization, laboratory } & 8 \\
\hline \multicolumn{2}{|c|}{ Maternity and Neonatal Unit } & 6 \\
\hline \multicolumn{2}{|c|}{ Wards for short term stay } & 4 \\
\hline \multicolumn{2}{|c|}{$\begin{array}{l}\text { Medical consulting room, Dental clinics, Diagnostic imaging department, Nutrition } \\
\text { and dietetics department }\end{array}$} & 2 \\
\hline \multicolumn{2}{|c|}{ Wards for long term stay } & 1 \\
\hline \multicolumn{2}{|c|}{ Physical risk associated with clinical application $(A)$} & \\
\hline \multicolumn{2}{|c|}{ Criterion } & Breakdown \\
\hline \multicolumn{2}{|c|}{ Potential patient or operator death } & 10 \\
\hline \multicolumn{2}{|c|}{ Potential injury to patient or operator } & 8 \\
\hline \multicolumn{2}{|c|}{ Inappropriate therapy or misdiagnosis } & 6 \\
\hline \multicolumn{2}{|c|}{ Interrupts patient's service } & 4 \\
\hline \multicolumn{2}{|c|}{ Minimum risk } & 2 \\
\hline \multicolumn{2}{|c|}{ No significant risk } & 1 \\
\hline \multicolumn{3}{|c|}{ Equipment Function (F) } \\
\hline \multicolumn{2}{|l|}{ Criterion } & Breakdown \\
\hline \multirow{3}{*}{ Therapeutic } & Life-support & 10 \\
\hline & Surgical and intensive care & 10 \\
\hline & Physical therapy and treatment & 9 \\
\hline \multirow{2}{*}{ Diagnostic } & Surgical and intensive care monitoring & 9 \\
\hline & Additional physiological monitoring and diagnostic & 8 \\
\hline \multirow{3}{*}{ Analytical } & Analytical laboratory & 6 \\
\hline & Laboratory accessories & 5 \\
\hline & Computers and related & 4 \\
\hline \multirow{3}{*}{ Other } & Patient related & 2 \\
\hline & Non-Patient related & 1 \\
\hline & Others & 1 \\
\hline & Maintenance requirement $(R)$ & \\
\hline Criterion & & Breakdown \\
\hline Routine calit & odic replacement of part(s) & 10 \\
\hline Performance & d safety testing & 5 \\
\hline Visual inspe & ats and cleaning & 2 \\
\hline & Equipment failure history per year $(H)$ & \\
\hline Criterion & & Breakdown \\
\hline 5 o more fail & & 10 \\
\hline 3-4 failures & & 5 \\
\hline 1-2 failures & & 2 \\
\hline & Usage intensity (IU) & \\
\hline Criterion & & Breakdown \\
\hline Permanent & & 10 \\
\hline By shift & & 5 \\
\hline Intermittent & & 2 \\
\hline & Availability $(D)$ & \\
\hline Criterion & & Breakdown \\
\hline Only & & 10 \\
\hline Abundance & & 5 \\
\hline
\end{tabular}

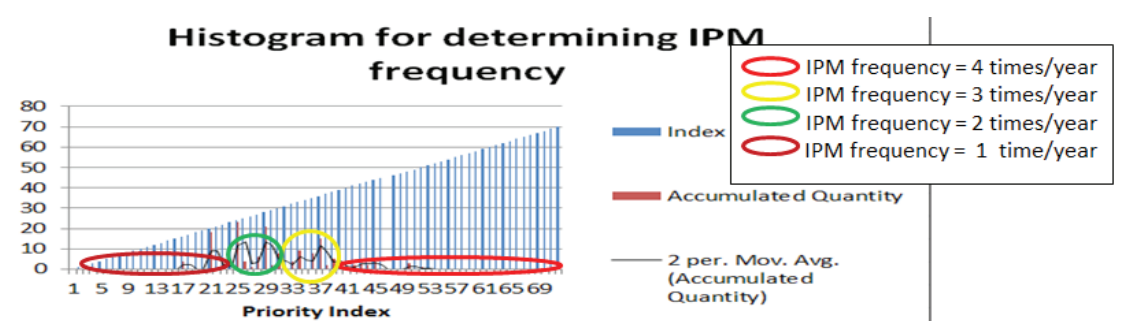

Figure 3. Histogram used to determine IPM frequency 
For the scheduling to be successful, at the start of each year a plan should be drafted with only those stable events and this is done by taking the following steps:

a) Identify the working days there are in each month and order them in a consecutive manner as only these days will be referred to.

b) Calculate the work load for each day.

c) Formulate a list of all the equipment to be maintained and sort them in a descending order, starting with those equipment classified as high risk.

d) Equipment classified in the same group should be further sorted in a likewise descending order starting with those of the highest priority index.

e) Maintenance is scheduled in such a manner that activities are assigned starting from the first working day, each time an activity is added to a day an accumulative of the hours to be dedicated to maintenance of those activities assigned to that day is stored.

f) When the accumulative sum becomes equal to the work load mentioned in part $b$, then the assignment is rolled over to the next consecutive working day and so on.

g) To complete the scheduling, maintenance activities which are outsourced are added to the plan.

\section{EXECUTION OF MAINTENANCE}

Execution of maintenance takes into account the manner in which scheduled IPM activities should be carried out:

1. One month before an IPM activity is due, all tools/ spare parts/materials should become available and an advisory note with information regarding the intervention and its duration sent to the end-users of equipment.

2. One week before the activity is due; the corresponding work order with the job specification (procedures) should be generated and assigned to the specialized technicians.

3. When executing the work, technicians should make note on his/her work order of his/her compliance to the written specifications and make note of other required fields on work order.

4. Once work is completed, an IPM tag should be placed on equipment. This tag should provide details on the current status of equipment; results of the work carried out and a notice of when will be the next IPM intervention.

5. All work sheet returned to the department should then be entered in a computerized system and the system updated.
6. For works which are outsourced, one week before the activity are due, the department should remind the contractors about the work.

7. Once the works are completed, the related information should then be entered in a computerized system for future references.

8. The heads of management in the department should make periodic evaluation of the work executed by the technicians with the objective of monitoring the competence of the workers and quality of the maintenance works produced by the department.

9. At least once per year, a committee comprising of safety officers and heads of maintenance department should be presented with performance indicators such as completion rate of assigned IPM, IPM yield etc. The objective of this committee should be identifying opportunities for improvement and if there are justification matters that can be raised should include: adjusting IPM frequency, outsourcing more or less works etc.

\section{Results AND DISCUSSION}

For the implementation phase, data was taken from the Bustamante Hospital for Children (BHC), Jamaica and was a one off experience done over a two month period. From the results it shows that the full implementation of this work can be a positive start to the continuous improvement in the operations management within the Biomedical Department of SERHAMU (South East Regional Health Authority Maintenance Unit) at the Bustamante Hospital for Children (BHC), Jamaica.

The results obtained can be separated into two groups namely: procedures on how to control efficiently the operations management and procedures on how to evaluate the operations management.

The procedure to control the operations is presented in the following aspects: a codification system, classification of equipment into different risk levels, calculation of priority index, scheduling and execution of maintenance. From the results, a codification system on how to establish an inventory number for control registers and types of equipment failure resulted in a more reliable and efficient system of monitoring the activities that are executed in the department. Classifying equipment into different risk levels and assigning them a priority index helped to prioritize maintenance works. The guideline presented on how to schedule and execute maintenance improved greatly the planning and carrying out of maintenance work.

The procedure to evaluate the operations is reflected mainly in the aspect where the calculation of the 
minimal amount of persons required in the department is presented. However to do so the following methods had to be presented: determination of the inspection and preventative maintenance frequency and calculation of the load of the annual maintenance plan.

Table 3 presents the calculations done for equipment within the sterilization specialty. Key factors such as: Maintenance Frequency (FM), Average hours to be dedicated to the maintenance of particular equipment family (HPE) and load of the annual maintenance plan (CPA) are highlighted. Applying Equations (1-2) we obtained values for CPA, FT and PO (see Table 3 and Table 4). This means that a minimum of 13 personnel is needed in the biomedical department. This is in disagreement with the present staffing in the department as in present days; only 8 personnel are being employed. This latter represents a $61.53 \%$ of optimum staffing (Table 4). This shortage of staff can be rectified by either employing more workers to the department or outsourcing more maintenance works.

Making reference to the proposed procedure on how to determine IPM frequency, a subsequent table (Table 5) was done with the objective of identifying the
IP intervals and the corresponding IPM frequency which would be assigned to equipment falling in those intervals. This procedure was carried out for equipment whose service manuals cannot be found.

\section{Conclusions}

In a previous study in 2013, the maintenance department that attends to the medical equipment at the Bustamante Hospital for Children was observed to have areas of weakness in its operations management. This deficiency is due to the lack of awareness by management personnel on the modern techniques being employed in maintenance management.

This work fulfils its objective by providing a procedure to evaluate and control efficiently the operations management in the said department. The method used to develop the procedure is called GOMHO. This work will provide management personnel with the necessary directions to be taken on the way forward. This procedure is flexible and allows room for continuous improvement as the department grows and thus be changing goals.

Table 3. Factors used to determine the CPA for the specialty of sterilization

\begin{tabular}{|c|c|c|c|c|c|}
\hline Specialty & Equipment Family & Quantity & FM & $\mathrm{HPE}(\mathrm{min})$ & CPA (min) \\
\hline \multirow{10}{*}{ Sterilization } & Oven & 10 & 2 & 30 & 600 \\
\hline & Mary bath & 7 & 2 & 45 & 630 \\
\hline & Autoclave & 14 & 3 & 120 & 5040 \\
\hline & Serologic bath & 5 & 3 & 45 & 675 \\
\hline & Stove & 2 & 2 & 30 & 120 \\
\hline & Floating tissue bath & 2 & $\overline{3}$ & 45 & 270 \\
\hline & Hematocrit centrifuge & 3 & 3 & 60 & 540 \\
\hline & $\mathrm{CO}_{2}$ incubator & 1 & 3 & 90 & 270 \\
\hline & Microscopy system & 3 & 3 & 120 & 1080 \\
\hline & Muffle & 2 & 2 & 30 & 120 \\
\hline & Total & & & & 9345 \\
\hline
\end{tabular}

Table 4. Values used to compare the amount of personnel needed versus the amount existing in the department

\begin{tabular}{|c|c|c|c|c|}
\hline Specialty & Quantity & $\begin{array}{l}\mathrm{CPA} \\
(\mathrm{min})\end{array}$ & $\begin{array}{c}\text { Amount of personnel } \\
\text { needed }\end{array}$ & $\begin{array}{c}\text { Amount of existing } \\
\text { personnel }\end{array}$ \\
\hline Electromecanical & 130 & 16200 & 1 & 0 \\
\hline Electromedical & 107 & 33999 & 2 & 1 \\
\hline Endoscopy & 15 & 600 & 1 & 0 \\
\hline Sterilisation & 49 & 9345 & 1 & 1 \\
\hline Dental & 27 & 1345 & 1 & 0 \\
\hline Imaging & 19 & 5900 & 1 & 0 \\
\hline Laboratory and electro-optics & 119 & 17820 & 1 & 1 \\
\hline Oftalmology & 63 & 5585 & 1 & 1 \\
\hline Medical optics & 24 & 910 & 1 & 0 \\
\hline Oxygen and gas systems & 73 & 25890 & 1 & 0 \\
\hline Operating salon and vaccum & 30 & 2140 & 1 & 0 \\
\hline Radiotherapy & 0 & 0 & 0 & 0 \\
\hline
\end{tabular}

Table 5. Intervals of priority index used to identify inspection and preventative maintenance frequency

\begin{tabular}{cc}
\hline IP & IPM Frequency/year \\
\hline$\geq 38$ & 4 times \\
$34-37$ & 3 times \\
$24-33$ & 2 times \\
$0-23$ & time \\
\hline
\end{tabular}


The results obtained here demonstrated that this procedure improved the format in which information is documented and processed in the department. It was also noted that there is an immediate need to employ five more technicians to the department to attend to the needs of this sole hospital. On the contrary a $38 \%$ of the works to be out sourced. It is of high recommendation the adaptation of the results obtained here into the operations management of not just the $\mathrm{BCH}$ but to all hospitals being managed by the SERHAMU and unto the other three regions in the country.

\section{ReferenCes}

Arnoletto E.J. and Díaz A.C. Un aporte a la gestión pública hacia nuevos enfoques en la gestión organizacional de la administración pública [monografía], Córdova, Argentina, 2009, pp. 147. ISBN: 978-84-692-4561-3.

Brousse L.T. Programa de mantenimiento preventivo. Equipos médicos críticos. Hospital Santiago Oriente, Chile, 2011, pp. 30.

Calzadilla T.C. Gestión de mantenimiento de la red hospitalaria del estado Anzoátegui, caso: Hospital Universitario Dr. Luis Razetti. CIENCIA ergo sum, volume 18 (issue 2), May-August, 2011 [on line] [Access: April 10, 2014]. Avaliable on: http://ergosum. uaemex.mx/index.php/ergosum/article/view/857.

Caro R.E. La gestión operativa y la gestión estratégica. 2012 [on line] [Access: April 7, 2012]. Avaliable on: http://www.administracionmoderna.com/2012/04/la-gestion-operativa-y-lagestion.html

Carrillo J.C.T. Diseño de un modelo de gestión de mantenimiento basado en la norma covenin 2500-93 para los sistemas de apoyo del área operativa del hospital "Dr. Héctor Nouel Joubert", (tesis Máster en Ingeniería Industrial), Universidad Experimental Politécnica "Antonio José De Sucre", Puerto ordaz. 2011, pp. 175 [on line] [Access: June 04 2014]. Avaliable on: http://www.monografias.com/trabajos87/ modelo-gestion-mantenimiento-hospital-dr-hector-noueljoubert/modelo-gestion-mantenimiento-hospital-dr-hectornouel-joubert.shtml\#ixzz36WT1aK6P

CCEEM. Reglamento para la Evaluación y el Control Estatal de Equipos Médicos [reglamento], Elfos Scientiae, La Habana, Cuba, 2008, pp. 162. ISBN: 78-959-235-027-2.

Correa C.T. ¿Que es la gestión operativa? 2012 [on line] [Access: March 19, 2014]. Avaliable on: http://gestionoperativadelasorganizaciones.blogspot.com/2012/12/que-es-las-gestion-operativa.html

David Y., Jahnke E., Blair C. Risk Assessment -Hospital View in Selecting Medical Technology. In: Engineering in Medicine and Biology Society, 2004. IEMBS'04. 26th Annual International Conference of the IEEE, San Francisco, 2004 pp. 3504-3504. ISBN 0-7803-8439-3 doi: 10.1109/IEMBS.2004.1403984

David Y. and Gullickson M. The role of cuantificable risk factor in a medical technology management program, volume 1 (issue
3), 1996 [on line] [Access: March 3, 2010]. Avaliable on: http:// www.researchgate.net/profile/Yadin_David/publications/2.

Dückers M., Faber M., Cruijsberg J., et al. Safety and risk management in hospitals, Health Foundation, 2009. ISBN: 1906461139.

INSALUD. Organización del mantenimiento en centros sanitarios [manual], Instituto Nacional de Salud, Madrid, España, 1990, pp. 168. ISBN: 84-351-0084- 7.

Jardine C., Hrudey S., Shortreed J., et al. Risk Management Frameworks for Human Health and Environmental Risks. Journal of Toxicology and Environmental Health Part B: Critical Reviews, volume 6 (issue 6), November-December, 2003 [on line] [Access: July 23, 2013]. Doi:http://dx.doi.org/10.1080/ 10937400390208608.

Márquez A.C., Márquez C.P., Fernández J.G., et al. Modelo Avanzado de Gestión de Mantenimiento. Proceso de Gestión y Técnicas de Soporte, Departamento de Organización Industrial y Gestión de Empresas Escuela Superior de Ingenieros. Universidad de Sevilla, España, 2008 [on line] [Access: March 22, 2014]. Available on: http://www.mantenimientomundial. $\mathrm{com} / \mathrm{sites} / \mathrm{mm} /$ notas/Modelo-Avanzado-Gestion.pdf.

Murillo W.O. and Mancera F.C. Caracterización de la gestión del mantenimiento de equipo biomédico en servicios de urgencia de clínicas y hospitales de Medellín en el período 2008-2009. Ciencia de la Salud, volume 11 (issue 1), April-July, 2013 [on line] [Access: April 10, 2014]. Avaliable on: http://revistas.urosario.edu.co/index.php/revsalud/article/view/2457.

Otero J.A., Arcique R.T., Jiménez D.M. Análisis de modos de falla, efectos y criticidad (AMFEC) para la planeación del mantenimiento empleando criterios de riesgo y confiabilidad. Tecnología, Ciencia, Educación, volume 25 (issue 1), 2010 [on line] [Access: June 16, 2014]. Avaliable on: http://www.redalyc. org/articulo.oa? id=48215094003.

Palmer H.A. and Fleitas M.T. Auditoria integral de mantenimiento en instalaciones hospitalarias, un análisis objetivo. Ingeniería Mecánica, volume 14 (issue 2), May-August, 2011 [on line] [Access: October 10, 2013]. Avaliable on: http://scielo.sld.cu/ scielo.php?pid=S1815-59442011000200003\&script=sci_arttext.

Puerta J.S.E. Gestion de Mantenimiento de equipos médicos en la fundación infantil Club Noel, (tesis ingeniero biomédico), Universidad Autónoma de Occidente, Colombia. 2011, pp. 130 [on line] [Access: June 04, 2014]. Avaliable on: http://bdigital.uao. edu.co/bitstream/10614/1141/1/TBM00269.pdf

SIC. Programa de acción específico 2007-2012. Gestión de equipo médico Secretaría de innovación y calidad, Ciudad de México, 2008, pp. 53.

Viveros P., Stegmaier R., Kristjanpoller F., et al. Propuesta de un modelo de gestión de mantenimiento y sus principales herramientas de apoyo. Ingeniare Revista chilena de ingeniería, volume 21 (issue 1), April 2013 [on line] [Access: March 22, 2014]. doi:http://dx.doi.org/10.4067/S0718-33052013000100011

Zavarce R. and Forero A. Modelo de gestión operativa para los servicios de tecnología de información en empresas de servi- 
cios públicos. Revista del Centro de Investigación de Ciencias Administrativas y Gerenciales, volume 10 (issue 1), 2012 [on line] [Access: January 14, 2014]. Avaliable on: http://www.publicaciones.urbe.edu/index.php/cicag/article/view/1675/3503.

\section{Suggested citation:}

\section{Chicago style citation}

Herrera-Galán, Michael, Shanique Natasha-Walker. Procedure to evaluate and control efficiently the operations management of medical equipment in the maintenance unit of a health institution. Ingeniería Investigación y Tecnología, XIX, 01 (2018): 1-10.

\section{ISO 690 citation style}

Herrera-Galán M., Natasha-Walker N. Procedure to evaluate and control efficiently the operations management of medical equipment in the maintenance unit of a health institution. Ingeniería Investigación y Tecnología, volume XIX (issue 1), January-March 2018: 1-10.

\section{AвOut the Authors}

Michael Herrera-Galán. Was born and raised in Cuba. He graduated from the Technological University of Havana José Antonio Echeverría UTH-CUJAE, with a bachelor's degree in Automatic Control Engineering in 2007 and consequently with a master's degree in Bioengineering in 2011. He is currently a PhD student in the Doctorate in Technology program at the Autonomous University of Ciudad Juárez, Chihuahua, México. He works as a specialist for science, technology and the environment at the National Center for Scientific Research (CNIC) and is the coordinator of Business Sciences discipline in the undergraduated program Biomedical Engineering, at Technological University of Havana José Antonio Echeverría UTH-CUJAE. His research topics are related with the hospital technological management, engineering and maintenance management, quality management and risk management in clinical-hospital institutions and biotechnology companies.

Shanique Natasha-Walker. Was born and raised in Jamaica. In 2008 she was granted a scholarship to study in Cuba. She is now a graduate from the University College José Antonio Echeverría (CUJAE), with a Bachelor's degree in Biomedical Engineering. She is now seeking to pursue a master's degree in her field of study. 